Jurnal Basicedu Volume 4 Nomor 2 April 2020 Hal. 484- 490

JURNAL BASICEDU

Research \& Learning in Elementary Education

https://jbasic.org/index.php/basicedu

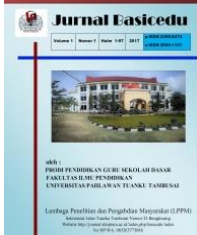

\title{
PENGGUNAAN MEDIA PEMBELAJARAN DALAM MODEL PICTURE AND PICTURE UNTUK MENINGKATKAN HASIL BELAJAR SISWA
}

\author{
Daryanti $^{1}$, Taufina ${ }^{2}$ \\ Universitas Negeri Padang, Sumatera Barat, Indonesia ${ }^{1,2}$ \\ E-mail : : daryantiweng4@gmail.com, taufinataufik@yahoo.co.id ${ }^{2}$
}

\begin{abstract}
Abstrak
Kegiatan Penelitian tindakan kelas ini bertujuan untuk membuktikan pengaruh penggunaan gambar dan gambar atau yang dikenal dengan model pelajaran picture anad picture terhadap hasil belajar siswa kelas VIA SD El-Ma'arif Pasaman Barat . Penggunaan gambar dalam pelajaran ini bertujuan untuk mengenalkan fakta tentang benua-benua yang ada di permukaan bumi sebelum konsep pelajaran tentang benua itu sendiri ditemukan. Diangkatnya penelitian ini dilatarbelakangi oleh keluh kesah siswa yang merasa bingung untuk menentukan letak negara tertentu di benua tertentu. Setelah diadakan pelajaran perbaikan ini diperolehlah hasil belajar siswa yang meningkat dari setiap tahapan atau siklus penelitian yang diadakan dari Dengan ratarata perolehan kelas 68,69 dengan persentase keberhasilan siswa di atas KKM 37,54\% menjadi rata-rata 89,5dengan tingkat keberhasilan siswa dari KKM ke atas mencapai 21 orang atau $91.7 \%$.
\end{abstract}

Kata Kunci : kemampuan mengidentifikasi ciri-ciri benua, IPS, Picture and Picture

\begin{abstract}
This class action research activity aims to prove the effect of the use of pictures and drawings or what is known as the picture anad picture lesson model on the learning outcomes of VIA elementary school students in El-Ma'arif Pasaman Barat. The use of images in this lesson aims to introduce facts about the continents that exist on the surface of the earth before the concept of learning about the continent itself was discovered. The appointment of this research was motivated by the frustration of students who felt confused to determine the location of a particular country on a particular continent. After this improvement lesson is obtained, student learning outcomes are improved from each stage or cycle of research conducted.
\end{abstract}

Keywords: ability to identify continental characteristics, IPS, Picture and Picture

@ Jurnal Basicedu 2020

$\triangle$ Corresponding author:

Address : Jambak Jalur V Timur Pasaman Barat

Email : daryantiweng4@gmail.com

ISSN 2580-3735 (Media Cetak)

Phone : 081363122193 


\section{PENDAHULUAN}

Dalam pelaksanaan ilmu sosial sebagai salah satu materi yang diajarkan maka dikembangkanlah materi yang dimulai dari seperangkat peristiwa sebagai fakta, dalam memperkenalkan konsep serta menyimpulkan sebagai generalisasi(Ayu Febriana, 2011). Pelajaran IPS ( Ilmu pengetahuan sosial ) merupakan bagian dari ilmu sosial yang harus dipelajari oleh siswa kelas VI sekolah dasar. Dalam pelaksanaanya perlu pemilihan model pelajaran yang sesuai, disebabkan pelajaran IPS adalah merupakan satu kesatuan yang tak terpisah disetiap cabangnya(Setyosari, Studi, Universitas, \& Malang, 2014)

Salah satu kompetensi dasar yang ada dalam pelajaran IPS kelas VI adalah mengidentifikasi benua-benua. Benua yang ada di dunia yang harus dipelajari di kelas enam ada lima benua. Benua merupakan dataran yang luas (Sri Wasono Widodo \&Mulyadi HP : 2008) Benua adalah daratan yang sangat luas dan dikelilingi oleh lautan( Irawan Sadad Sadiman \&Shendy Amalia :2009). Begitu banyaknya benua serta luasnya benua yang harus dipelajari kelas enam, membuat siswa tersebut kurang berminat. Bukan hanya siswa saja ada beberapa pendidik yang merasa kewalahan untuk menyampaikan pelajaran ini. Demikian pula yang terjadi pada siswa - siswa kelas VI A SD ELMA'ARIF Kecamatan Luhak Nan Duo Pasaman Barat tempat kami melaksanakan tugas.

Pada saat menyampaikan pelajaran dengan standar kompetensi (SK) 1. Memahami perkembangan wilayah Indonesia kenampakan alam dan keadaan sosial negara-negara di Asia Tenggara serta benua-benua kompetensi dasar (KD) 1.3 Mengidentifikasikan benua-benua dengan indikator : 1) Menunjukkan pembagian wilayah di dunia, 2) Menjelaskan ciri khas dari tiap benua, 3) Menyebutkan nama negara di masing-masing benua. Penulis telah menemukan indikasi kalau pelajaran ini tidak menyenangkan bagi siswa VI A SD EL-MA'ARIF Kecamatan Luhak Nan Duo Pasaman Barat. Hal ini terlihat pada saat pertemuan pertama membahas mengenai benua ASIA. Benua ASIA sebagai tempat tinggal kita yang begitu dekat dengan diri kita siswa memperlihatkan wajah bosan, kesal, serta keluh kesah yang tersampaikan melalui lisan mereka. Masih banyak siswa yang pasif dalam kegiatan belajar IPS, hal serupa juga ditemui dalam penelitian ( Putra, 2017, Ni Made Ayu Santi Paramitha, 2019)

Mengukur dan mengingat pelajaran sebelumnya tentang pembagian wilayah benua Asia bagian timur dan selatan. Penulis meminta beberapa siswa yang ditunjuk secara acak untuk menemu tunjukan tentang negara-negara yang ada di benua tersebut. Lalu kenampakan alam yang menjadi ciri khas negara-negara tertentu di kedua wilayah bagian benua Asia tersebut dari 24 siswa yang ada di kelas tersebut hanya 3 orang yang dengan gembira berlari ke depan kelas untuk menemutunjukannya. Jika dihitung secara persen maka didapat informasi hanya $12,5 \%$ yang tertarik dengan pelajaran ini. Jika diruntut dari peraturan tentang ketuntasan kelas 75\% siswa menguasai dari $75 \%$ materi yang disampaikan. Jelas pelajaran awal ini menunjukan sinyal kegagalan dari pembelajaran yang penulis sampaikan.

Kriteria ketuntasan minimal yang menjadi tolak ukur dari keberhasilan pembelajaran pada Kompetensi dasar (KD) adalah 80. Berdasarkan hasil awal dari pengamatan yang penulis lakukan dengan melakukan perbandingan 1/ 18 materi yang disampaikan telah mengalami kegagalan sebanyak 4,4\% ini jelas akan mempengaruhi minat dan keinginan siswa hanya $16 \%$ yang tertarik sementara $84 \%$ yang lain tidak tertarik ini akan menjadi masalah yang harus segera diselesaikan. 
Pada saat menyampaikan pelajaran tersebut penulis sudah mencoba menyampaikannya dengan menggunakan media peta, dibantu pula dengan penggunaan LCD proyektor serta laptop dengan asumsi penggunaan media dalam pembelajaran sebagai bentuk peningkatan mutu(Zahroh, 2017) serta dapat meningkatkan pengetahuan siswa terhadapa tehnologi untuk kebaikan mereka dimasa depan(Taufina, Chandra, \& Kharisma, 2019) Tetapi penulis masih merasakan ketidak nyamanan siswa dalam menggali ilmu tersebut. Hipotesa yang penulis tarik dari pembelajaran awal yang penulis lakukan adalah kurang merakyatnya pelajaran tersebut pada siswa. Seperti kesimpulan dialog penulis kepada siswa dimana siswa meminta untuk pelajaran ini didesain seperti game. Menurut mereka pelajaran ini susah untuk diingat. Untuk memudahkan siswa dalam menginggat pelajaran maka dipilihlah model pelajaran yang dapat membantu mengingat yaitu picture and picture(Hanim, Suci, Rosyidah, Asitah, \& Aini, 2018)

Berdasarkan permintaan siswa-siswa kelas VI A SD EL-MA'ARIF Kecamatan Luhak Nan Duo Pasaman Barat. Penulis akan mencoba melakukan penelitian tindakan kelas dengan menggunakan media pelajaran dalam model pelajaran picture and picture. Dengan judul penelitian Peningkatan kemampuan mengidentifikasi ciri-ciri benua pada pelajaran IPS dengan menggunakan media pembelajaran dalam model picture and picture di kelas VIA SD EL-MA'ARIF Kecamatan Luhak Nan Duo Pasaman Barat.

\section{METODE PENELITIAN}

Jenis penelitian ini adalah penelitian tindakan kelas yang terdiri dari 2 siklus dimana masing-masing siklus terdiri dari empat tahapan yaitu perencanaan, pelaksanaan, observasi dan refeleksi. Penelitian ini dilaksanakan di SD ElMa'arif Kecamatan Luhak Nan Duo Pasaman Barat.SD El-Ma'arif adalah sekolah swasta yang memiliki dua tempat dalam pelaksanaan pendidikannya. Subjek penelitian ini adalah siswa kelas VI A SD El-Ma'arif Kecamatan Luhak Nan DuoPasaman Barat.Jumlah siswanya adalah 24 orang yang terdiri dari 9 putri dan 13 putra. Penelitian tindakan kelas ini dilakukan pada semester I tahun pelajaran 2017-2018. Penelitian ini dilakukan dari bulan Oktober sampai November 2017. Teknik pengumpulan data menggunakan observasi, tes dan dokumentasi. Data dianalisis menggunakan persentase dan reduksi data.

\section{HASIL PENELITIAN DAN PEMBAHASAN}

Setelah dilaksanakan pelajaran perbaikan pada siklus I diperoleh hasil belajar sebagai berikut :

Tabel 1. Hasil Belajar siklus I

\begin{tabular}{||c|c|c|c|c|}
\hline NO & SKOR(S) & $\begin{array}{c}\text { FREKUENSI } \\
\text { (f) }\end{array}$ & s x f \\
\hline 1 & 100 & 0 & $0 \%$ & 0 \\
\hline 2 & 90 & 7 & $29,2 \%$ & 630 \\
\hline 3 & 80 & 2 & $8,32 \%$ & 160 \\
\hline 4 & 70 & 7 & $29,2 \%$ & 490 \\
\hline 5 & 60 & 3 & $12,5 \%$ & 180 \\
\hline 6 & 50 & 2 & $8,32 \%$ & 100 \\
\hline 7 & 40 & 0 & $0 \%$ & 0 \\
\hline 8 & 30 & 2 & $8,32 \%$ & 60 \\
\hline 9 & 20 & 0 & $0 \%$ & 0 \\
\hline 10 & 10 & 0 & $0 \%$ & 0 \\
\hline 11 & 0 & 1 & $4,14 \%$ & 0 \\
\hline & Jumlah & 24 & $100 \%$ & 1620 \\
\hline
\end{tabular}


487 Penggunaan media pembelajaran dalam model picture and picture untuk meningkatkan hasil belajar siswa - Daryanti, Taufina

Dengan rata-rata perolehan kelas 68,69 dengan persentase keberhasilan siswa di atas KKM $37,54 \%$. Berdasarkan table perolehan pada siklus I tersebut diperoleh data bahwa pada kegiatan perbaikan I ini siswa yang mencapai keberhasilan dengan KKM 80 adalah 9 orang. Berdasarkan data tersebut maka diadakan kegiatan perbaikan siklus II dengan mengadakan perbaikan dari kelemahan yang ada pada siklus I yang diperoleh informasi dari teman sejawad sebagai obsever.

mewujudkan cita-cita dari pendidikan seperti yang tertuang dalam UU Sisdiknas. Menggunakan media sebagai alat untuk mengangkat atau menimbulkan persoalan untuk dikaji lebih lanjut oleh siswa dalam proses pembelajaran menjadi ajang latihan bagi siswa dalam mengembangkan kemampuan keterampilan menulis menyampaikan ide, pendapat secara tulisan dengan teratur dan sesuai dengan aturan menulis bukanlah hal yang mudah bagi seorang siswa terutama siswa sekolah dasar

Tabel 2. Hasil belajar siklus 2

\begin{tabular}{||c|c|c|c|c|}
\hline NO & SKOR(S) & $\begin{array}{c}\text { FREKUENSI } \\
\text { (f) }\end{array}$ & $\%$ & s x f \\
\hline 1 & 100 & 11 & $45,83 \%$ & 1100 \\
\hline 2 & 90 & 4 & $16,7 \%$ & 360 \\
\hline 3 & 80 & 7 & $29,20 \%$ & 560 \\
\hline 4 & 70 & 1 & $4,2 \%$ & 70 \\
\hline 5 & 60 & 1 & $4,2 \%$ & 60 \\
\hline 6 & 50 & 0 & $0 \%$ & 0 \\
\hline 7 & 40 & 0 & $0 \%$ & 0 \\
\hline 8 & 30 & 0 & $0 \%$ & 0 \\
\hline 9 & 20 & 0 & $0 \%$ & 0 \\
\hline 10 & 10 & 0 & $0 \%$ & 0 \\
\hline 11 & 0 & 0 & $0 \%$ & 0 \\
\hline & Jumlah & 24 & $100 \%$ & 2150 \\
\hline & \multicolumn{5}{|l}{} \\
\hline
\end{tabular}

Pada kegiatan perbaikan siklus II ini diperoleh rata-rata 89,5. Berdasarkan table perolehan data tersebut maka hasil perolehan ada siklus II telah mencapai KKM dengan tingkat keberhasilan siswa dari KKM ke atas mencapai 21 orang atau $91.7 \%$.

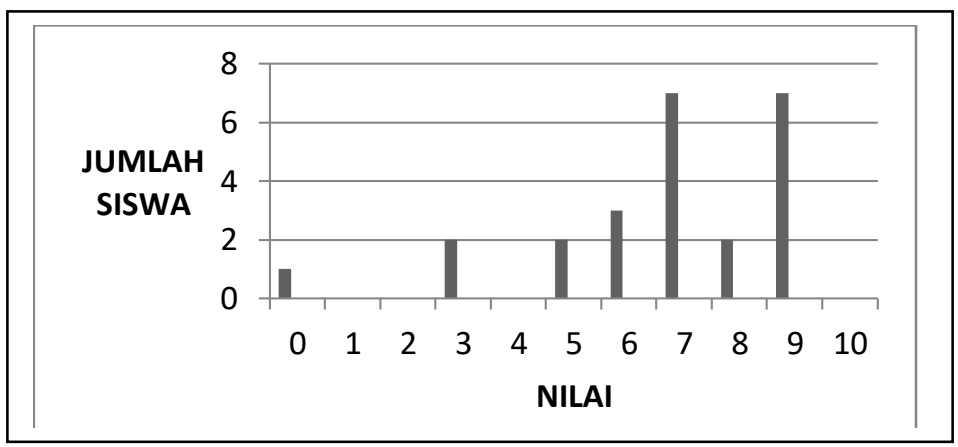

\section{Grafik 1.Hasil belajar}

Berdasarkan data serta tabel di atas diperoleh informasi tentang perbaikan pembelajaran model picture and picture menggunakan media pembelajaran menggunakan media peta lengkap, peta buta serta kartu nama ini pada siklus I diperoleh rata-rata hasi belajar 62,28 . Ada 17 orang siswa yang belum tuntas dengan kriteria ketuntasan belajar (KKM) 80 . Jika dihitung secara persentase maka 62,5\% siswa belum berhasil. Siswa yang memperoleh nilai ratarata KKM dan di atas KKM adalah 7 orang atau 27,5 \%. Kegagalan kelas menjadi kegagalan klasikal.

Kelemahan yang terjadi pada siklus I ini secara penilaian dari hasil diskusi denga teman sejawat serta kometar siswa adalah sebagai berikut :Media yang dipakai penulis belum jelas sekali atau tidak detail berbeda dengan gambar peta pada lembar kerja siswa.. Pembelajaran belum penulis mulai dengan ekplorasi yang maksimal dalam penggunaan media..Soal yang diberikan belum mewakili dari seluruh isi pembelajaran.. Pengorganisasian kelompok belajar belum tepat, sehigga ditemukan siswa yang tidak 
peduli dengan pelajaran. Siswa dalam kelompok hanya menitipkan jawaban kepada teman lain dalam kelompoknya. Mengakibatkan rendahnya aktifitas siswa yang bersangkutan. Terindikasi dalam perolehan hasil belajar siswa yang bersangkutan karena guru kurang dalam mengaktifkan siswa secara merata. Siswa merasa senang dengan model pelajaran picture and picture. Siswa merasa terbantu dengan adanya media pembelajaran

Berdasarkan kelemahan yang diperoleh dari pelaksanan perbaikan pembelajaran siklus I. Dilaksanakanlah perbaikan pembelajaran siklus II dengan melakukan perbaikan pada : Penyempurnaan media pembelajaran dengan menambah kartu nama negara serta kenampakan alam, serta menebalkan garis pembatas antara wilayah pada Benua Australia sehiggamendekati kesesuaian dengan lembar kerja siswa. Memaksimalkan pemberian materi pembelajaran pada pertemuan sebelumnya dengan kegiatan diskusi kelompok. Menggunakan media peta lengkap dan media peta buta pada awal pembelajaran serta melakukan diskusi kelas tentang materi Benua Australia yang telah dibahaskan tampa peta pada hari sebelumnya dipelajaran ini, sebagai kegiatan eksplorasi untuk temu tunjuk serta tanya jawab materi. Menambah soal yang penyebarannya mewakili seluruh pembelajaran. Pengorganisaian kelompok belajar dari 5 atau 6 orang menjadi 2 orang atau teman sebangku. Sehingga setiap siswa secara tidak langsung terpaksa untuk aktif dalam pembelajaran.

\section{Setelah dilakukan perbaikan} pembelajaran berdasarkan hasil refleksi dari masukan teman sejawat serta masukan siswa maka diperoleh hasil belajar pada siklus II adalah 89,5

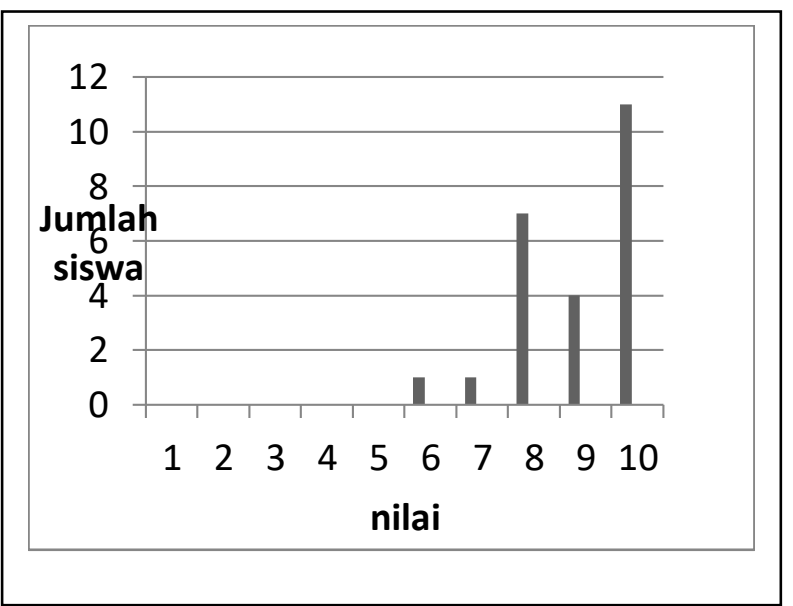

Grafik 2. Hasil belajar siklus 2

Berdasarkan grafik persebaran nilai pada setiap siklus diatas diperoleh beberapa informasi : Pada perbaikan pembelajaran siklus I . Perbaikan pembelajaran menggunakan media dengan model pembelajaran picture and picture masih ditemukan banyak kelemahan baik pada pembutan media atau pun pemakaian model pembelajaran. Pada perbaikan pembelajaran siklus II telah banyak perkembangan perbaikan pembelajaran. Terindentifikasi dari jumlah siswa yang tidak tuntas yaitu 2 orang. Karena pelajaran ini merupakan pelajaran kedua dari Benua yang sama yaitu Australia.

Berdasarkan hasil refleksi dari teman sejawat serta komentar siswa kelemahan dari model pelajaran picture and picture menggunakan media pembelajaran ini adalah gambar yang belum sesuai dengan ukuran kartu nama. Hal ini juga sesuai dengan kelemahan dari pelajaran model pelajaran picture and picture yaitu 
Kelemahan dari pemakaian model ini adalah Tidak mudah didapatkan gambar yang sesuai dengan materi yang akan disampaikan. Tidak mudah meneukan gambar yang dapat disesuaikan dengan kemampuan berfikir peserta didik.. Belum terbiasanya guru dan siswa menggunakan model ini. Perlu disediakan alokasi dana, untuk menyesuaikan gambar yang dibutuhkan.

Kelebihan dari pembelajaran ini dari hasil diskusi dengan teman sejawat dan komentar siswa adalah : Model yang menyenankan bagi siswa. Media yang digunakan dapat membantu menjelaskan materi.. Terjalin kerjasama dalam kelompok belajar

Hal ini sesuai dengan fungsi dari media pembelajaran menurut Asep Herry Hermawan (2008 : hal 11.22) diantaranya : Menimbulkan kegairahan belajar. Menfokuskan/menarik perhatian. Mendekatkan interaksi langsung dengan lingkungan nyata. Menimbulkan persepsi yang sama.

Kelebihan yang dirasakan menggunakan model pembelajaran ini yaitu : Mudahnya mencapai tujuan pembelajaran sebagai sasaran akhir, karena pelajaran ini telah samapikan walau singkat. Dengan batuan gambar, siswa dengan mudahnya menagkap materi pelajaran. Meningkatnya kemampuan analisa siswa melalui gambar-gambar yang ada.. Tanggung jawan siswa mulai diasah melalu tanya jawab tentang alasan dari kegiatan susunan gamabar yang dibuatnya. Menyenangkannya pembelajaran yang ditempuh siswa meningkatkan kebermaknaan dari pelajaran itu sendiri.

\section{SIMPULAN}

Dengan menggunakan media pembelajaran dalam model picture and picture dapat meningkatkan kemampuan mengidentifikasi ciri-ciri benua pada pelajaran IPS di kelas VIA SD EL-MA'ARIF Kecamatan Luhak Nan Duo Pasaman Barat yang ditandai dengan adanya peningkatan dari siklus ke siklus yang ditunjukan sebagai hasil dari penelitian yang dilaksanakan. Dengan rata-rata perolehan kelas 68,69 dengan persentase keberhasilan siswa di atas KKM $37,54 \%$ menjadi rata-rata 89,5dengan tingkat keberhasilan siswa dari KKM ke atas mencapai 21 orang atau $91.7 \%$. Secara signifikan model pembelajaran ini berhasil mempengaruhi hasil belajar siswa kelas VIA SD EL-MA'ARIF Kecamatan Luhak Nan Duo Pasaman Barat

\section{DAFTAR PUSTAKA}

Ayu Febriana. (2011). ( APPLICATION OF COOPERATIVE LEARNING MODEL TYPE MAKE A Ayu Febriana Teacher at Primary School Kalibantengkidul 1 , Semarang Abstract. KREATIF Jurnal Kependidikan Dasar, 1, 151-161.

Hanim, S., Suci, A., Rosyidah, E., Asitah, N., \& Aini, N. (2018). Learning from Picture and Picture Action Research: Enhancement of Counting Ability on Division of Numbers for Primary School Students Learning from Picture and Picture Action Research: Enhancement of Counting Ability on Division of Numbers for Primary School Students.

Sadad Sadiman,Irawan .( 2009) Ilmu Pengetahuan Sosial 6 : SD/MI Kelas VI .Jakarta : Pusat Perbukuan, Departemen Pendidikan Nasional

Setyosari, P., Studi, P., Universitas, P. D., \& Malang, N. (2014). Kualitas Pembelajaran Ips Dalam Penerapan Model Problem Besed Learning. Pendidikan Humaniro, 1-5. 
490 Penggunaan media pembelajaran dalam model picture and picture untuk meningkatkan hasil belajar siswa-Daryanti, Taufina

Sudjana,Nana dan Ahmad Rivai.(2011).Media

Pengajaran.Bandung. Sinar baru

Algensindo

Taufina, Chandra, \& Kharisma, A. (2019).

Technology integration in thematic learning to welcome the era of the industrial revolution 4 . 0 in elementary schools. Proceeding Internasional Seminar of Primary Education, 2, 10-19. https://doi.org/https://doi.org/10.24114/esjpg sd.v9i1.14297

Taufina, T., Chandra, C., Fauzan, A., \& Ilham Syarif, M. (2019). Development of Statistics in Elementary School Based RME Approach with Problem Solving for Revolution Industry 4.0. https://doi.org/10.2991/icet-19.2019.172

Wasono Widodo. Sri dan Mulyadi HP.(2008) .Ayo Belajar Sambil Bermain Il Pengetahuan Sosial: untuk SD/MI kelas VI/oleh. — Jakarta: Pusat Perbukuan, Departemen Pendidikan Nasional.

Zahroh, N. L. (2017). PENGEMBANGAN MEDIA PEMBELAJARAN TERPADU BERBASIS APLIKASI FREEMIND DALAM MENINGKATKAN KUALITAS PEMBELAJARAN IPS DI JURUSAN PGMI FAKULTAS ILMU TARBIYAH DAN KEGURUAN UIN MAULANA MALIK IBRAHIM. Jurnal PIPSI (Jurnal Pendidikan IPS Indonesia), 1(2), 43. https://doi.org/10.26737/jpipsi.v1i2.304 